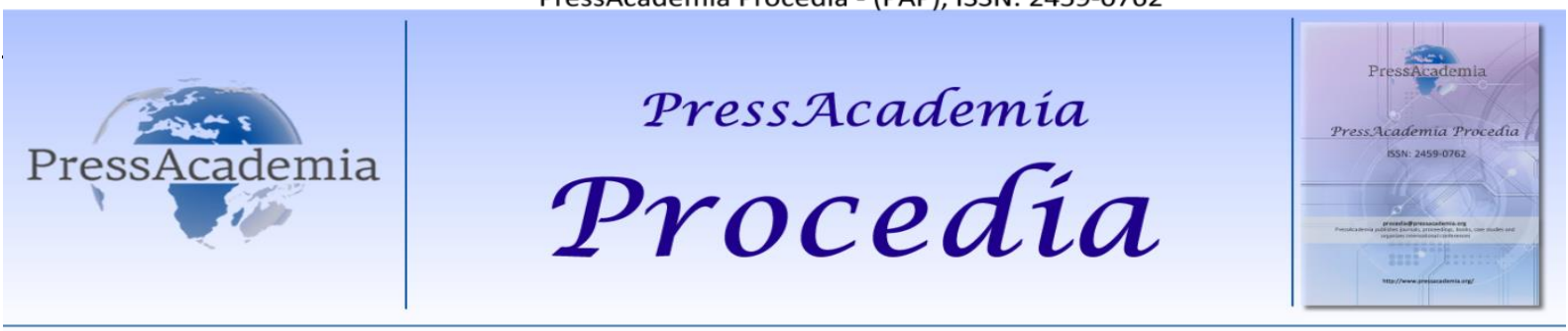

Istanbul Finance Congress (IFC), November 2-3, 2017, Istanbul, Turkey

\title{
THE IMPACT OF GLOBAL FINANCIAL CRISIS ON THE FINANCIAL STRUCTURE OF SHIPPING INDUSTRY IN TURKEY AND ANALYSIS OF NORMALIZATION PROCESS DURING 2008-2015
}

\author{
DOI: 10.17261/Pressacademia.2017.744 \\ PAP-IFC- V.6-2017(8)-p.43-47
}

\section{Engin Kurun ${ }^{1}$, Tansel Erkmen ${ }^{2}$}

${ }^{1}$ Piri Reis University, Tuzla, Istanbul, Turkey. ekurun@pirireis.edu.tr

${ }^{2}$ Piri Reis University, Tuzla, Istanbul, Turkey. terkmen@pirireis.edu.tr

\section{To cite this document}

Kurun, Engin and Erkmen, Tansel, (2017). The Impact of Global Financial Crisis on the Financial Structure of Shipping Industry in Turkey and Analysis of Normalization Process During 2008-2015. PressAcademia Procedia (PAP), V.6., p.43-47.

Permanant link to this document: http://doi.org/10.17261/Pressacademia.2017.744

Copyright: Published by PressAcademia and limited licenced re-use rights only.

\begin{abstract}
Objective- The main purpose of this study is to investigate the impact of global financial crisis on the financial structure of shipping industry in Turkey. According to the BRSA figures as of Dec. 2016, water transportation sector performed the highest (154.9\%) non performing loan increase year to date among all other sectors. This research will throw light on the main resons of this situation and will also contribute the better understanding of the financial structure of maritime companies.

Methodology- The data related to company accounts were obtained from Central Bank of the Republic of Turkey (CBRT) for 2008-2015. C301 Building of Ships and Boats data series and H-502 Sea and Coastal Freight Water Transport data series are selected to show the impact of global financial crisis on the shipping industry. Main balance sheet and income statement data as well as financial ratios were published by CBRT regularly for 2008-2015 in three years interval. We aggregated them and analyzed to show the structural change in financial preferences and adequacy of capital, liquidity and similar performance figures.

Findings- The global financial crisis is affected the Turkish shipping industry as a whole. The equity funds accounted for around $47 \%$ in 2008 but decrease to $36 \%$ in 2011 and recovered again up to $40 \%$ at the end of 2015. In terms of financial structure of the sector, current liabilities almost doubled in last 8 years from $12.5 \%$ to $25 \%$. It is resulted with especially worsen liquidity ratio such as cash ratio decreased from $78.5 \%$ to $17.3 \%$. The global financial crisis adversely affected the profitability of the sector with an unstable and volatile profit margin and increased service and operating costs.

Conclusion- In conclusion there is no normalization sign after 2008 in the shipping industry in Turkey. We observed a gradual growth in the World trade. However historically lower freight rates and imbalances in the shipbuilding industry cause debt burden and huge losses for the maritime companies. This reseaach findings can be used as a benchmark for the maritime companies to better understand their performance since 2008.
\end{abstract}

Keywords: Maritime transport, shipping industry, global financial crisis, ratio analysis, financial performance. JEL Codes: M40, G30

\section{INTRODUCTION}

Normalization refers to a process that makes something more normal or regular. The availability of cash, with the construction of more technologically advanced ships, with the expansion of ports and the introduction of new shipping services, the cargo capacity in terms of twenty-foot equivalent units (TEU) of the world container fleet, had more than tripled between the years 2000-2009, reaching 12.5 million. But now, the well-known global financial and economic crisis of 2008 had almost overnight suppressed the growth of the container-ships market. In fact, for the first time in the history of the maritime industry, growth has stopped and there is even a steady decline in the rate of containers shipped around the world. In the first six months of the year of the crisis alone, the shipping industry declined by close to $16 \%$ causing huge losses. As international trade slows and freight rates for transporting goods across the world's seas and oceans decline, shipping revenues have been hit. A slowdown in international trade growth couldn't have come at a worse time-a period where capacity has been expanding faster than global demand-for the shipping industry. Not surprisingly, capacity expansion-a lot of which is often fueled by borrowing - has increased the debt burden for some shipping companies, especially since 2009-10. 
Though still facing a slow recovery, but the dry market shipping price will come to normalization this year (2017), according to Maritime Financial Research Drewry. The dry bulk shipping market price, according to Drewry, has actually started in June 2016, though it had argued that "the long-awaited normalization process has already begun in the dry bulk shipping. The total gross weight of goods handled in EU ports is estimated at just above 3.8 billion tones in 2015, an increase of $1.3 \%$ from 2014. According to the latest figures, the EU port freight activity seems to have resumed on a slight path towards recovery in 2014, a trend that was sustained in the four quarters of 2015. Compared with 2014, The Turkish port freight activity were increased by $8.7 \%$ in 2015.

In our view the normalization provides opportunity over the next few years. The sector is becoming a supply-side story rather than demand, which has been the case for much of the last decade.

The main purpose of this study is to investigate the impact of global financial crisis on the financial structure of shipping industry in Turkey. According to the BRSA figures as of Dec. 2016, water transportation sector performed the highest (154.9\%) non performing loan increase year to date among all other sectors. This research will throw light on the main reasons of this situation and will also contribute the better understanding of the financial structure of maritime companies.

\section{LITERATURE REVIEW}

The global financial and economic crisis of 2008 has made vulnerable the intricate chain of activity which comprises the maritime industry. Midoro, R., Musso, E., and Parola, F. (2005) analyzed the last decade was a period of significant change in container shipping as liner companies had to face, on the demand side, the new needs of shippers due to globalisation while, on the supply side, chronic fleet overcapacity. Rodrigue, J.P.; Comtois, C. and Slack, B. (2009) explained succinctly in their research how this change occured. The 20 largest carriers controlled $26 \%$ of the world slot capacity in 1980, $42 \%$ in 1992 and about $58 \%$ in 2003. Those carriers have the responsibility to establish and maintain profitable routes in a competitive environment. The development of the shipping industry has gone hand-in-hand with changes in port organization. According to a recent study for the European Parliament, ports have undergone major transformations in their organizational structures (European Parliament Directorate (2009)). According to Stopford (2009) with every passing decade (business cycle) ship financing techniques have been evolving in response to changes in the overall shipping market itself. These changes in the shipping industry also regularly result in freight rate and capacity fluctuations. Stephenson Harwood (2006) stated despite the fact that shipping, with the progression of time, has embraced numerous sources of finance, bank debt still dominates as the main source of capital. Drobetz \& Merikas (2013) proved unfortunately, however, for shipping, access to bank capital since the beginning of the crisis in shipping has suffered a drastic blow. Drobetz et al (2013) proved debt capital has traditionally been the most important source of external finance in the shipping industry and this remains the case. Their research provides evidence that leverage works counter cyclical, with the speed of adjustment to be significantly lower during economic recessions. Finally, researchers argue that shipping industry will suffer from reductions in the available finance capital in the future, because the shipping banks will reduce the finance capital due to regulations and small margins from asset investments. According to the findings of OECD research (2017) among 114 publicly traded shipbuilding companies, the operating profitability of shipbuilding companies decreased from around $10 \%$ in 2010 to about $4 \%$ in 2014 . Shipbuilding companies showed better profitability rates in 2006 than in 2014 and a higher number of yards experienced negative EBITDA margins in 2014 than in 2006.

Sayılgan and Uysal (2011) investigated capital structure determinants of Turkish firms based on Turkish Central Bank Industrial Balance Sheets survey data set from 1996 to 2008 which is not used before for a capital structure study. Empirical results imply that non-debt tax shield has negative; but size, tangibility, profitability, growth opportunities and bankruptcy (financial distress) risks has positive relation with capital structure. Financial risk indicators for the non-financial firms analyzed by CBRT (2016) by using the financial accounts statistics in 2016. These indicators are: ratio of debt to GDP; debt to operating surplus, debt to equity and ratio of liabilities to financial assets. In the analyzed period, the ratio of the corporate sector's total debt to GDP displayed an uptrend until 2015 as global liquidity headed for emerging economies after the financial crisis and these countries enjoyed favorable financing facilities, then remained flat and lastly was recorded at 0.68 percent in the final quarter of 2016. Similarly, the ratio of debt to equity displayed an uptrend through the same period. This ratio stayed at 1.02 percent in 2016Q4. The ratio of debt to operating surplus shows if the business profits of non-financial corporations are able to cover debt repayments. This ratio followed a limited uptrend and was recorded at 4.5 by the end of 2015. Meanwhile, the ratio of the sector's liabilities to financial assets (leverage indicator) was 1.5 in the final quarter of 2016.

\section{DATA, MODEL, FINDINGS, ANALYSIS}

The data related to company accounts were obtained from Central Bank of the Republic of Turkey (CBRT) for 2008-2015.

$>\quad$ C-301 Building of Ships and Boats

> H-502 Sea and Coastal Freight Water Transport

data series are selected to show the impact of global financial crisis on the shipping industry.

Main balance sheet and income statement data as well as financial ratios were published by CBRT regularly for 2008-2015 in three years interval. We aggregated them and analyzed to show the structural change in financial preferences and adequacy of capital, liquidity and similar performance figures. Mainly liquidity ratios, ratios of financial positions, turnover ratios and profitability ratios as well as interest coverage ratios analysed for $\mathrm{C}-301$ and $\mathrm{H}-502$ series for 8 years. Total 47 performance figures used and selected ratios compared with the required benchmarks to measure the impact of global financial crises. 
Table 1: Number of companies in each segment

\begin{tabular}{|lllllllll|}
\hline Code & 2008 & 2009 & 2010 & 2011 & 2012 & 2013 & 2014 & 2015 \\
\hline C-301 & 46 & 46 & 46 & 33 & 28 & 24 & 33 & 25 \\
\hline H-502 & 68 & 68 & 68 & 75 & 71 & 51 & 56 & 53 \\
\hline
\end{tabular}

Data classification was revised in 2009 and published under the new series since 2010. We used the most recent data published by CBRT for each year. It is observed that almost $50 \%$ of total shipbuilding companies did not disclose their financial figures to CBRT. There might be size effect for these results.

We tried to explore the financial structure of shipping industry in Turkey with the CBRT raw data. We did not analyzed the H-501 Sea and Coastal Passenger Water Transport because of low level data availability (less than 12 observation) at 2015.

\section{Findings for Shipbuilding}

$\checkmark \quad$ Equity funding was around 15\% in 2008 while it is increased to $22 \%$ in 2011 and dropped again to $10 \%$ as of year end 2015 in the ship building sector. (Figure-1)

$\checkmark \quad$ Another interesting point here is the shift in the asset composition in favour of current assets. We observed that the current assets reached from $37.5 \%$ to $58 \%$ respectively for the years 2008 and 2015.

$\checkmark \quad$ This figure is mainly stemmed from the liquidity preference of the companies in addition to substantial increase in trade receivables. Average payback period of receivables is increased from 35 days to 83 for the years 2008 and 2015 respectively.

$\checkmark \quad$ We also supported our findings with the worsen liquidity and profitability ratios after 2008. Enormous decrease (from $54 \%$ to $20 \%$ ) in weight of tangible assets (net) over total assets is the sign of invested capital is negatively affected after the global financial crises.

$\checkmark \quad$ Global financial crises affected negatively the profitability of the ship building sector with unstable and volatile profit margins and increasing production cost and operating expenses. (Figure-1)

Figure 1: Selected findings for Shipbuilding industry in Turkey
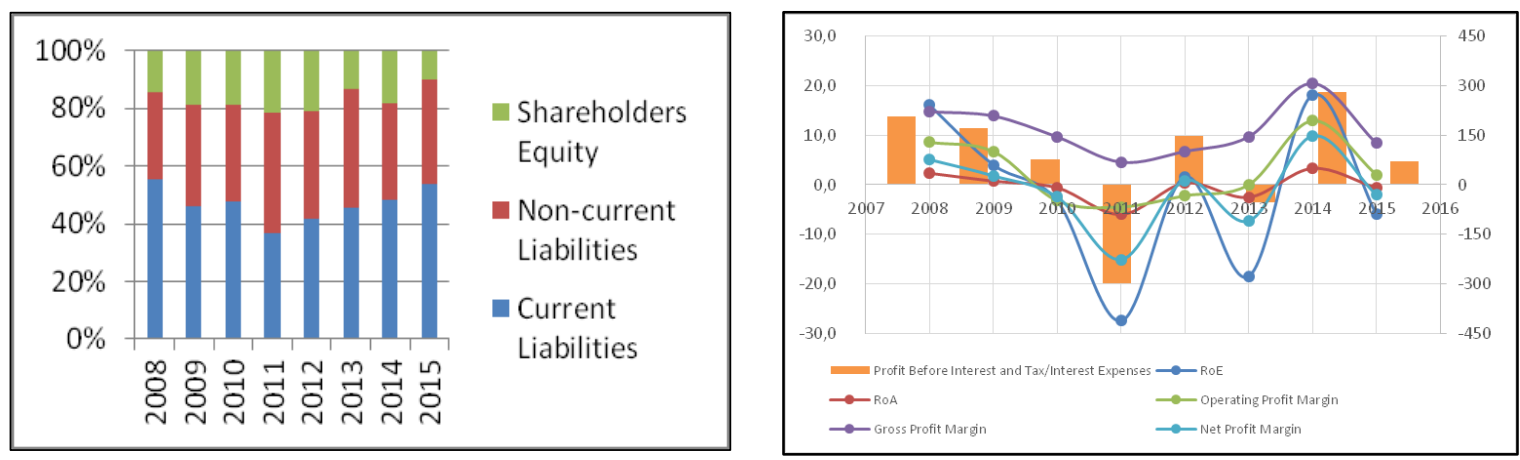

Source: CBRT, Authors' own calculation

\section{Findings for Maritime Transportation}

Similar findings are valid for the maritime transportation sector. Maritime sector in Turkey as a whole is affected by global financial crisis and the main outcome of this impact is reflected on the equity of the companies.

$\checkmark \quad$ The equity funding was around $47 \%$ in 2008 while it is decreased to $36 \%$ in 2011 and recovered again to $40 \%$ as of year end 2015 in the sea and coastal freight water transport sector. (Figure-2)

$\checkmark \quad$ In terms of financial structure of the sector, current liabilities almost doubled in last 9 years from $12.5 \%$ to $25 \%$. It is resulted with especially worsen liquidity ratio such as cash ratio decreased from $78.5 \%$ to $17.3 \%$.

$\checkmark \quad$ Short term receivable is the most affected portion of current assets. Global financial crises affected negatively the profitability of the sector with unstable and volatile profit margins and increasing service cost and operating expenses.

$\checkmark \quad$ Gross profit margin, operating profit margin decreased from $25 \%$ to $10 \%$ and $19 \%$ to $3 \%$ respectively during the observed period. Debt burden, unstable and volatile ROE and net profit margin prove the ongoing effects of the crises. (Figure-2) 
Figure 2: Selected findings for Maritime Transportation
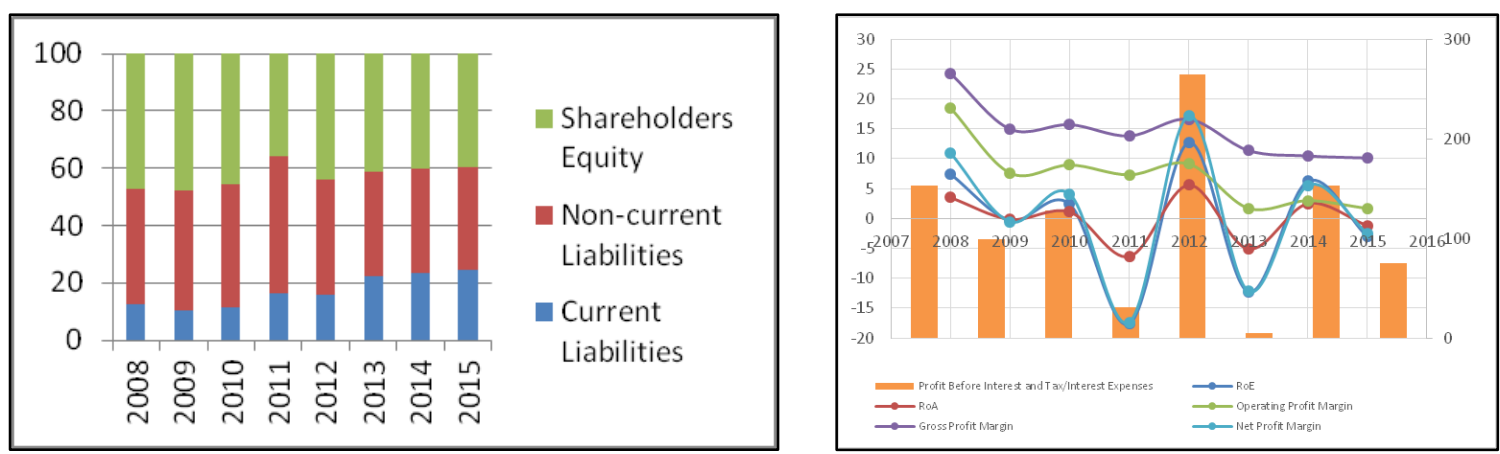

Source: CBRT, Authors'own calculation

We also compared our findings with the manufacturing industry and transportation industry for the last five years. Shipbuilding industry is the subset of manufacturing industry while it covers $24-33$ companies itself against 3,421-3,803 manufacturing companies. Shipbuilding industry performance figures are generally below average of manufacturing industry in terms of liquidity, leverage, turnover ratios and profitability ratios. Manufacturing industry show signs of $v$ shape recovery while shipbuilding industry operating profit margin and interest coverage ratios are still in trouble. Maritime transportation industry is the subset of transportation and storage industry while it is composed of 51-75 companies itself against 342-406 transporatation companies. The liquidity of the maritime transportation firms are below average while performed as average of benchmark industry figures in turnover ratios and ratios of financial positions. Interest expenses to net sales figures prove the debt burden of firms and ongoing unstable profit margins.

\section{CONCLUSION AND DISCUSSION}

The global financial crisis is affected the Turkish shipping industry as a whole. Equity funding was around $15 \%$ in 2008 while it is increased to $22 \%$ in 2011 and dropped again to $10 \%$ as of year end 2015 in the shipbuilding sector. Similar but less speed capital loss observed in the manufacturing sector, but the financing is replaced by long term loans. However financing gap is funded with short term loans in shipbuilding sector and this preference negatively effected liquidity and profitability ratios. The equity funding was around $47 \%$ in 2008 while it is decreased to $36 \%$ in 2011 and recovered again to $40 \%$ as of year end 2015 in the sea and coastal freight water transport sector. Same intention to use short term funds also observed here while the transportation and storage sector funded itself with long term loans. Representation rate for each sector is low.

Global financial crises affected negatively the profitability of the ship building and sea and coastal freight water transport sectors with unstable and volatile profit margins and increasing production cost and operating expenses. In conclusion there is no normalization sign after 2008 in the shipping industry in Turkey. We observed a gradual growth in the World trade. However historically lower freight rates and imbalances in the shipbuilding industry cause debt burden and huge losses for the maritime companies. We explored the impact of global financial crisis in the shipping industry by using company accounts statistics of CBRT. This reserach findings can be used as a benchmark for the maritime companies to better understand their performance since 2008 .

\section{REFERENCES}

Berman, N. et al., (2012). Time to Ship during Financial Crises. NBER International Seminar on Macroeconomics, 9(1), pp.225-260. Available at: http://www.jstor.org/stable/info/10.1086/669587. (Erişim tarihi: 29.09.2017)

Central Bank of Republic of Turkey (2016). Financial Accounts Report.

Drobetz, W., \& Merikas, A. G. (2013). Editorial. Transportation Research Part E, pp. 1-2.

Drobetz, W., Gounopoulos, D., Merikas, A., \& Schroeder, H. (2013). Capital structure decisions of globally-listed shipping companies. Transportation Research Part E, pp. 49-76.

Easton, P.D., McAnally, M.L., Sommers, G.A., Zhang, X.J. (2015). Financial Statement Analysis \& Valuation. 4th edition, Cambrige Business Publishers.

European Parliament Directorate General for Internal Policies (2009). The Involving Role of EU Seaports in Global Maritime Logistics Capacities, Challenges and Strategies. PE 419.121.

Midoro, R., Musso, E., and Parola, F. (2005). "Maritime Liner Shipping and the Stevedoring Industry: Market Structure and Competition Strategies." Maritime Policy \& Management 32 (2): 89-106.

OECD WP6 (2017). Imbalances in the Shipbuilding Industry and Assessment of Policy Responses.

Rodrigue, J.P., Notteboom, P., Pallis, A.A. (2011). The financialization of the port and terminal industry: revisiting risk and embeddedness. Maritime Policy and Management, Vol. 38, Issue 2, pp. 191-213. 
Rodrigue, J.P.; Comtois, C. and Slack, B. (2009). The Geography of Transport Systems. 2nd edition. Routledge, New York.

Sayılgan, G \& Uysal, B. (2011). "Türkiye Cumhuriyet Merkez Bankası Sektörel Bilançoları kullanılarak sermaye yapısını belirleyen faktörler üzerine bir analiz: 1996-2008” Ankara Üniversitesi, SBF Dergisi, Cilt 66, No 4, s. 101-124.

Stephenson Harwood. (2006). Shipping Finance. Euromoney Books.

Stopford, M. (2009). Maritime Economics. London: Routledge.

Subramanyam, K. R. And Wild, J.J., (2009). Financial Statement Analysis. 10th Edition, New York, NY, McGraw- Hill Irwin.

Widiantoro, D.M. \& Elvenes, V. (2012). Managing Risk in Financial Risk in Financial Market in Shipping. ACRN Journal of Finance and Risk Perspectives, Vol. 1, Issue 1, pp. 32-49.

CBRT (2016). Definitions of the Ratios http://www3.tcmb.gov.tr/sektor/2016/Raporlar/eng/oran-ing.pdf. (Erişim tarihi: 28.09.2017).

http://www3.tcmb.gov.tr/sektor/2016/menu eng.php. (Erişim tarihi: 28.09.2017)

http://www.denizticaretodasi.org.tr/sayfalar/dergi.aspx. (Erişim tarihi: 29.09.2017) 